\title{
FEEDBACK REGULATION BY OESTRADIOL OF OVARIAN FUNCTION IN JAPANESE QUAIL
}

\author{
MILTON H. STETSON* \\ Department of Zoology, University of Washington, \\ Seattle, Washington 98105, U.S.A. \\ (Received 24th September 1971, accepted 23rd February 1972)
}

\begin{abstract}
Summary. Feedback regulation of gonadotrophin release from the adenohypophysis by $17 \beta$-oestradiol was examined in breeding female Japanese quail. Implants of the steroid in the preoptic-supraoptic (nuclear) regions, in ventral regions of the infundibular nuclear complex or in the adenohypophysis resulted in a 'persistent oestrous'-like syndrome. Ovulation was prevented, but the weight and follicular size of the ovary and the weight of the oviduct did not differ from control (cholesterol implants or oestradiol implants outside of the hypothalamus) values. Since implants of cholesterol in identical regions of the hypothalamus had no effect on ovarian function, and since ovulation recurred in 10 or 16 days, depending on the site of implantation, the effects observed are attributed directly to the hormone contained in the implant and not to a physical obstruction in the hypothalamus. It is suggested that oestradiol is involved in the regulation of release of LH from the adenohypophysis.
\end{abstract}

\section{INTRODUCTION}

Considerable attention has been given to steroid regulation of ovarian function (particularly ovulation) in mammals (for review see Flerkó, 1966, 1967; Harris \& Campbell, 1966; Davidson, 1969). Two varieties of feedback phenomena have been described, one stimulating the release of gonadotrophins from the adenohypophysis and the second inhibiting the release of these hormones (see Barraclough \& Haller, 1970; Davidson, Weick, Smith \& Dominguez, 1970; Weick \& Davidson, 1970; Arimura \& Schally, 1971).

In males of several avian species, intrahypothalamic implants of testosterone prevent photoperiodically induced testicular growth (Gogan \& Kordon, 1964; Kordon \& Gogan, 1964, 1970; Gogan, 1967, 1968; Wilson, 1970) and result in regression of fully mature testes in breeding birds (Stetson, 1971, 1972). It appears that testosterone feedback is inhibitory in nature; pituitary gonadotrophic potency is reduced and, depending on the location of the implant, the testes appear histologically to be deficient either in LH (or LH and FSH) or in FSH (Gogan, 1968; Stetson, 1971, 1972).

Relatively few investigations of the oestrogenic control of ovarian function in avian species have been reported (see Parkes \& Emmens, 1944; Lorenz, 1954;

* Present address: Department of Zoology, University of Texas, Austin, Texas 78712, U.S.A. 
Kobayashi, 1954; Fraps, 1954, 1955; Heald, Rookledge, Furnival \& Watts, 1968; Stetson, 1971 and unpublished). Because of the paucity of data available, it was decided to test the presence of a feedback of $17 \beta$-oestradiol on the hypothalamo-hypophysio-ovarian axis of breeding Japanese quail.

\section{MATERIALS AND METHODS}

Laying female Japanese quail were housed with a male in a small wire compartment $(15.5 \times 20 \times 24 \mathrm{~cm})$, ten of which constituted one tier in a bank of breeding cages. Experimental treatment of both members of a breeding pair was identical, except that males received testosterone or cholesterol while females received $17 \beta$-oestradiol or cholesterol; analysis of the results in males has been dealt with previously (Stetson, 1972). Experimental birds were continually within sight and sound of normal breeding pairs. Environmental conditions were kept constant at $16 \mathrm{hr}$ light per day, and 22 to $28^{\circ} \mathrm{C}$. Food and water were continually available.

Stereotaxy (Stetson, 1968) under ether anaesthesia (Stetson, 1969a) was used to implant either fine glass capillaries $(0.05$ to $0.1 \mathrm{~mm}$ i.d.) or 22-gauge stainless steel tubing $(0.4 \mathrm{~mm}$ i.d.) in the brains of experimental animals. The capillaries were filled with cholesterol or $17 \beta$-oestradiol, as described by Gogan (1968). After implantation, the capillaries were cut off at the surface of the brain in which they remained firmly implanted (Pl. 1, Figs 1, 5 and 6) and were removed only after the brains had been fixed in Bouin's fluid. In other experiments, a pellet of oestradiol : charcoal ( $1: 1$ by weight) or cholesterol : charcoal $(1: 1)$ was implanted through a stainless steel tube. A wire plunger was withdrawn $0.5 \mathrm{~mm}$, and the steroid : charcoal mixture was tapped into the tube. After cleaning the tube externally with ethanol, it was inserted into the brain to a depth of approximately $0.5 \mathrm{~mm}$ dorsal to the target. The plunger was then depressed, forcing the pellet into the brain. The tube was then withdrawn. The cylindrical pellets, approximately $0.4 \times 0.5 \mathrm{~mm}$, weighed on the average ( \pm S.E.) $36.5 \pm 1.6 \mu \mathrm{g}$ (cholesterol: charcoal) and $29 \cdot 6 \pm 1 \cdot 7 \mu \mathrm{g}$ (oestradiol : charcoal).

\section{EXPLANATION OF PLATE 1}

Frontal sections through the hypothalamus of Japanese quail from Groups 1 to 5 showing location of the implant.

Fig. 1: Group 1. Arrow indicates location of the tip of a glass capillary that contained cholesterol. The growth of glial elements into the tube (arrow) indicates that the brain was in continual contact with the steroid within the tube. Paraldehyde thionin, $\times 34$.

Figs 2 and 3. Group 2. Implants of oestradiol : charcoal in the ventral infundibular nuclear region of a bird from the short-term experiment (Fig. 2) and one of the long-term experiments (Fig. 3 ). The bird in Fig. 2 did not ovulate during the 14 days of the experiment. Postovulatory delay to the resumption of ovulation in the bird in Fig. 3 was 16 days. Paraldehyde thionin, $\times 34$ (Fig. 2), $\times 28$ (Fig. 3).

Fig. 4. Group 3. Implant of oestradiol : charcoal that had no effect on ovarian function. Paraldehyde thionin, $\times 34$.

FIG. 5. Group 4. Section through the preoptic region of the hypothalamus showing the location (arrow) of a glass capillary containing oestradiol that suppressed ovulation for 6 days. Paraldehyde thionin, $\times 34$.

Fig. 6. Group 5. Section through the preoptic region of the hypothalamus showing location of a glass capillary containing oestradiol that did not affect ovarian function. Contract between steroid and nervous elements is attested by growth (arrow) of tissue into the capillary. Paraldehyde thionin, $\times 34$. 
PLATE 1
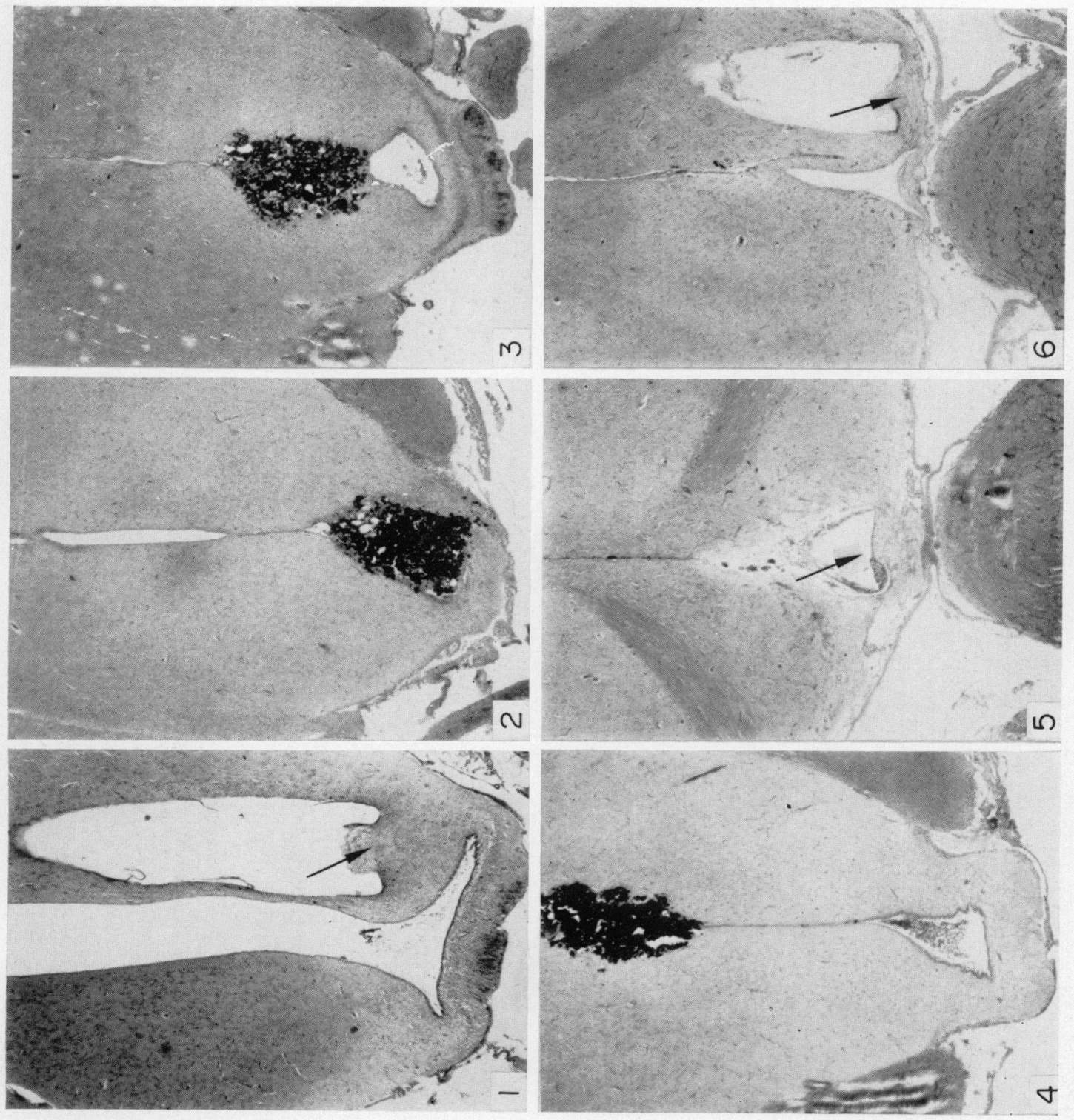

(Facing p. 206) 
Three experiments were designed to assess the long-term ( 33 to 35 days) and short-term (13 to 14 days) effect of oestradiol on the hypothalamo-hypophysioovarian axis. At the end of each experiment, the birds were decapitated and the adenohypophysis was immediately removed and desiccated in acetone (see below). The ovary and oviduct were removed and weighed to the nearest milligram on a Mettler analytical balance. The brain, ovary and oviduct were fixed in Bouin's fluid for 4 days. The brain was examined histologically (see Stetson, 1969a, 1971, for details) to verify placement of the implant.

TABLE 1

OVARIAN-OVIDUCAL WEIGHT AND FOLLIGULAR DIAMETER IN GONTROL AND EXPERIMENTAL GROUPS OF JAPANESE QUAIL

\begin{tabular}{|c|c|c|c|c|c|c|}
\hline \multirow{2}{*}{$\begin{array}{c}\text { Group } \\
(n)\end{array}$} & \multirow{2}{*}{$\begin{array}{l}\text { Location of } \\
\text { implant* }\end{array}$} & \multirow{2}{*}{$\begin{array}{l}\text { Ovary-oviduct } \\
\text { weight }(\mathrm{g})\end{array}$} & \multicolumn{4}{|c|}{ Follicle diameter $(\mathrm{mm})$} \\
\hline & & & $f_{1}$ & $f_{2}$ & $f_{3}$ & $f_{4}$ \\
\hline $\begin{array}{l}1(19) \\
2 \quad(7) \\
3(20) \\
4 \quad(7) \\
5(13)\end{array}$ & $\begin{array}{l}\text { Control implants } \\
\text { V-INC, ME, PD } \\
\text { ING } \\
\text { POR, SOR } \\
\text { POR, SOR }\end{array}$ & $\begin{array}{r}9 \cdot 060 \pm 0.597 \\
8 \cdot 345 \pm 0.807 \\
9 \cdot 340 \pm 0.438 \\
10 \cdot 311 \pm 1 \cdot 124 \\
9 \cdot 715 \pm 0.681\end{array}$ & $\begin{array}{l}15.59 \pm 0.66 \\
15 \cdot 33 \pm 0.74 \\
15 \cdot 68 \pm 0.57 \\
15 \cdot 81 \pm 0.78 \\
16.14 \pm 0.49\end{array}$ & $\begin{array}{l}11.84 \pm 0.69 \\
11 \cdot 10 \pm 0.81 \\
11.52 \pm 0.57 \\
12.24 \pm 1.40 \\
12.38 \pm 0.65\end{array}$ & $\begin{array}{l}8 \cdot 02 \pm 0.62 \\
7 \cdot 34 \pm 0.80 \\
7 \cdot 57 \pm 0.54 \\
9 \cdot 31 \pm 1 \cdot 40 \\
8 \cdot 67 \pm 0.72\end{array}$ & $\begin{array}{l}4 \cdot 89 \pm 0 \cdot 38 \\
4 \cdot 41 \pm 0 \cdot 30 \\
4 \cdot 65 \pm 0 \cdot 59 \\
5 \cdot 81 \pm 1 \cdot 10 \\
5 \cdot 30 \pm 0.59\end{array}$ \\
\hline
\end{tabular}

Results expressed as Mean \pm S.E.

* ING = infundibular nuclear complex; $\mathrm{ME}=$ median eminence; $\mathrm{PD}=$ pars distalis; $\mathrm{POR}=$ preoptic region of the hypothalamus; $\mathrm{SOR}=$ supraoptic (nuclear) region of the hypothalamus; V-INC=ventral region of the infundibular nuclear complex (includes the nucleus tuberis).

\section{TABLE 2}

PREOPERATIVE AND POSTOPERATIVE OVULATORY FREQUENGIES, POSTOPERATIVE DELAY TO RESUMPTION OF OVIPOSITION, AND PITUITARY GONADOTROPHIC POTENCY IN GONTROL AND EXPERIMENTAL GROUPS OF JAPANESE QUAIL

\begin{tabular}{|c|c|c|c|c|}
\hline Group & $\begin{array}{c}\text { Preoperative } \\
\text { frequency } \\
\text { (eggs/day) }\end{array}$ & $\begin{array}{c}\text { Postoperative } \\
\text { frequency } \\
\text { (eggs/day) }\end{array}$ & $\begin{array}{l}\text { Delay } \\
\text { (days) }\end{array}$ & $\begin{array}{c}\text { Pituitary } \\
G T H^{*}\end{array}$ \\
\hline $\begin{array}{l}1 \\
2 \\
3 \\
4 \\
5\end{array}$ & $\begin{array}{l}0.8 \pm 0.03 \\
0.7 \pm 0.03 \\
0.7 \pm 0.03 \\
0.7 \pm 0.04 \\
0.7 \pm 0.04\end{array}$ & $\begin{array}{l}0.7 \pm 0.05 \\
0.2 \pm 0.05 \dagger \\
0.6 \pm 0.02 \\
0.3 \pm 0.05 \dagger \\
0.7 \pm 0.05\end{array}$ & $\begin{array}{c}3 \cdot 4 \pm 0 \cdot 6 \\
16 \cdot 6 \pm 3 \cdot 0 \dagger \\
3 \cdot 8 \pm 0 \cdot 6 \\
10 \cdot 4 \pm 1.8 \dagger \\
3 \cdot 2 \pm 0.7\end{array}$ & $\begin{array}{l}2 \cdot 7 \pm 0.1 \\
2 \cdot 9 \pm 0.05 \\
2 \cdot 6 \pm 0.2 \\
2 \cdot 8 \pm 0.1 \\
2 \cdot 6 \pm 0.1\end{array}$ \\
\hline
\end{tabular}

Results expressed as Mean \pm S.E.

* Pituitary gonadotrophic potency in $\mu$ g-equivalents of NIH-LH-s13 or s15 per gland. $\uparrow$ Significantly different from controls $(P<0.001)$.

In addition to ovarian and oviducal weight, several other criteria were used to monitor the effects of implants on ovarian function. Oviposition was recorded during, and for several weeks before, each experiment; ovulatory frequencies were expressed as the number of eggs laid per day, e.g. $0 \cdot 75=$ three eggs laid in 4 days. Daily records indicated the postoperative delay to the resumption of oviposition. Finally, the four largest follicles from every ovary were measured with a pair of vernier callipers.

After each experiment, the adenohypophysis of each bird was pooled with 
glands from other birds in which implants in similar locations had a similar effect on ovarian function. The gonadotrophic potency (in $\mu$ g-equivalents of NIH-LH-s12 or s15) of the pooled glands was determined by the method of

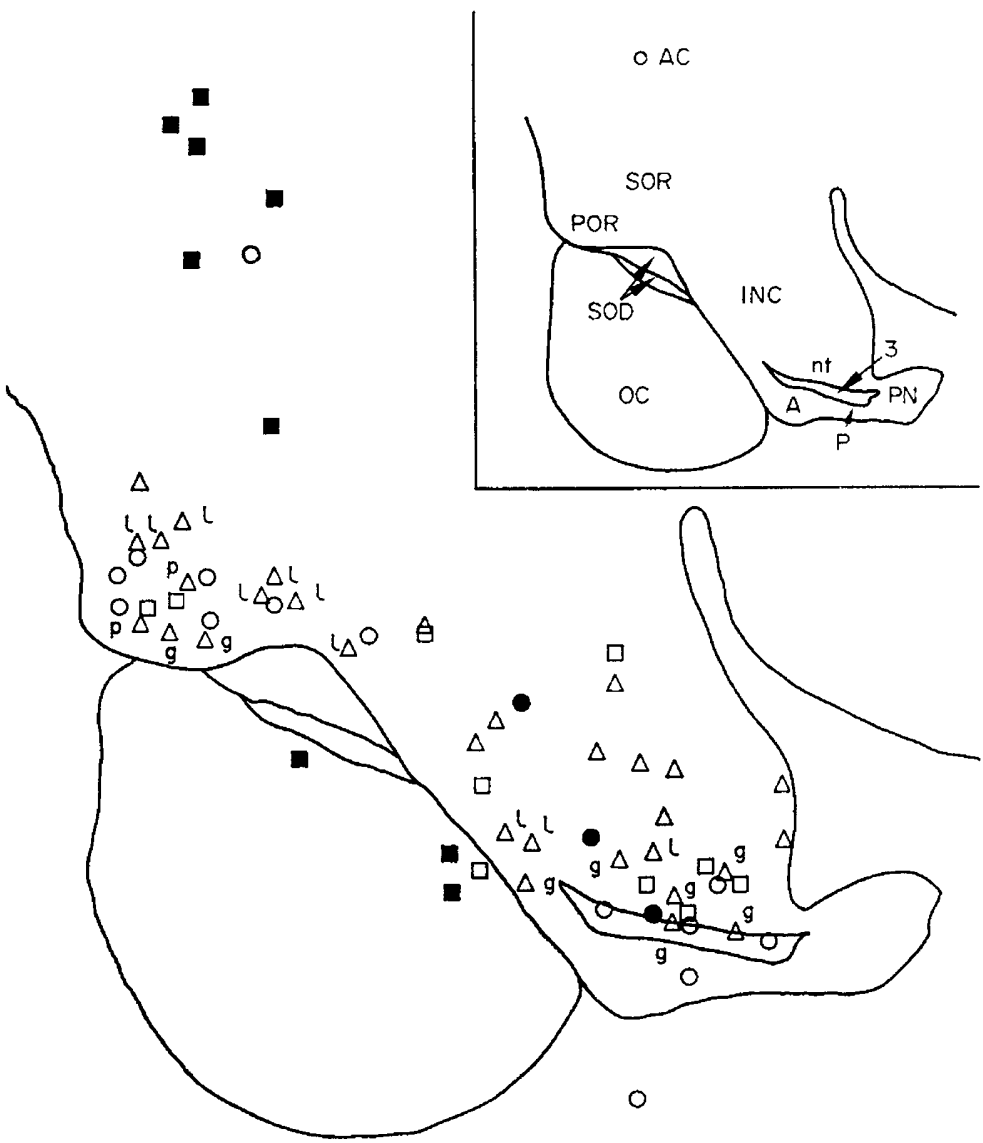

TexT-FIG. 1. Diagrammatic representation of the location of the implants on a midsagittal plane of the ventral hypothalamus of the Japanese quail. $\square$, Control implants of cholesterol; $\mathbf{\square}$, control implants of oestradiol; $O$, effective implants that resulted in a significant postoperative delay to the resumption of ovulation; $\bullet$, one pellet that broke within the third ventricles, leaving fragments in the locations indicated, the main body of the pellet being located just dorsal to the median eminence; $\Delta$, ineffective implants of oestradiol; $g$, glass capillary, located just lateral to mid-line; 1 , pellet of oestradiol : charcoal located laterally in the region of the hypothalamus indicated; $p$, pellet of oestradiol : charcoal located in the mid-line. Unmarked triangles indicate implants in mid-line that are excluded from the 'sensitive zone'. All symbols represent either the approximate centre of a pellet or the tip of a glass capillary. Insert: A, anterior division of the median eminence; AC, anterior commissure; INC, infundibular nuclear complex; nt, nucleus tuberis (included in this report in the ventral INC); OC, optic chiasma; $\mathbf{P}$, posterior division of the median eminence; PN, pars nervosa; POR, preoptic region; SOD, supraoptic (nuclear) region; 3 , third ventricle.

Breneman, Zeller \& Creek (1962) as modified by Follett \& Farner (1966). The assays were of the ' $2+2$ ' design and were analysed statistically as described by Bliss (1952). All other statistical analyses were determined with Student's $t$ test. 


\section{RESULTS}

The control group, Group 1, contained nineteen birds, ten of which received implants of cholesterol, while nine others received oestradiol implants that were placed incorrectly in the forebrain of the optic chiasma or optic tracts (PI. 1, Fig. 1; Text-fig. 1). Regardless of the composition of the implant, the postoperative delay to the onset of oviposition, the ovarian and oviducal weights and the follicular dimensions (Tables 1 and 2) were identical to those of control groups in investigations of the effects of hypothalamic lesions (ovarian-oviducal weight $=10.269 \pm 0.299 \mathrm{~g}$; delay $=3.2 \pm 0.7$ days $)$ or transections $(8.775 \pm 0.718 \mathrm{~g}$; $3.41 \pm 1.3$ days) on ovarian function (Stetson, 1971).

Seven birds received implants of oestradiol in ventral regions of the infundibular nuclear complex and median eminence. These birds (Group 2, Table 1, Text-fig. 1; PI. 1, Figs 2 and 3), had an average postoperative delay to oviposition of 15 to 17 days (Table 2). Four of these, from one of the long-term experiments ( 35 days' duration), had postoperative delays that were greater than the duration of the short-term experiments (13 to 14 days); the lengthiest delay was 33 days. From the short-term experiment, three birds which complete Group 2, failed to ovulate after receiving implants of oestradiol. Five of the seven implants were in postero-ventral regions of the infundibular nuclear complex and/ or posterior division of the median eminence, one was dorsal to the anterior division of the median eminence, and one was in the cephalic lobe of the pars distalis (Text-fig. 1, Table 1). All implants were located in, or immediately lateral to, the mid-line. At autopsy, the ovaries of all seven birds, including the three in which resumption of ovulation had not yet occurred, were similar in weight and follicular size to those of the controls of Group 1 (Table 1), and pituitary gonadotrophic potency in the two groups was nearly equivalent (Table 1). Both the postoperative delay to the resumption of oviposition and the postoperative frequency of ovulation in Group 2 were significantly different from control values (Table 2).

Oestradiol implanted into the infundibular nuclear complex of twenty other birds (Group 3) failed to affect the ovarian control system (Tables 1 and 2). The majority of implants were located dorsal to those in Group 2 (see Text-fig. 1), but seven were located in nearly identical locations. Six of these (one implant resided in the caudal lobe of the pars distalis) were glass capillaries of small diameter; the seventh was in pellet form and was located to the right of mid-line in the infundibular nuclear complex, just dorsal to the 'effective area' of Group 2 (Text-fig. 1). Histological examination of the implantation sites revealed that the oestradiol within the glass capillaries was in contact with neural tissue since there had been growth of glial elements into the tubes as the oestradiol was dissolved. Three other implants located in the ventral infundibular nuclear region were displaced laterally. The hypothalamo-hypophysio-ovarian axis in the birds in Group 3 was, in all respects, similar to that of the birds in Group 1 (Tables 1 and 2). Group 3 can, therefore, be taken as an experimental control group for Group 2.

In the seven birds of Group 4, oestradiol implants in the preoptic and supraoptic regions of the hypothalamus (see Text-fig. 1) resulted in a significant delay 
to the resumption of oviposition (Table 2). Six of the seven implants were medial (Pl. 1, Fig. 5) in location; the seventh was located dextrolaterally in the preoptic region and, in addition, had severed the ipsilateral tractus septomesencephalicus. The significantly greater postoperative delay to the onset of oviposition in Group 4 was coincident with the statistically smaller postoperative ovulatory frequency which was similar to that of Group 2 (Table 2). In addition, the average pituitary gonadotrophic potency of Group 4 was also similar to that of Group 2 (Table 2). The ovarian and oviducal weight and follicular diameter of the birds in Group 4 did not differ statistically from those in Group 1 (Table 1).

An additional thirteen females (Group 5) also received implants of oestradiol in the preoptic and/or supraoptic regions of the hypothalamus (Table 2). The majority of implants were dorsal and/or lateral to those in Group 4 (Pl. 1, Fig. 6 ), but four were similarly placed; two of these were glass capillaries containing oestradiol, which, from the growth of glial elements into the capillary (see Text-fig. 1; Pl. 1, Fig. 6), were presumably in continual contact with neural tissue. The two other implants were in pellet form, and were located in the preoptic recess and adjacent tissue and in the preoptic region, just to the right of the mid-line. The hypothalamo-hypophysio-ovarian axis in the birds of Group 5 was normal in every category investigated (Tables 1 and 2); Group 5 can, therefore, be regarded as an experimental control group for Group 4.

\section{DISCUSSION}

The foregoing experiments appear to be the first attempt to demonstrate a potential feedback from the ovary to the hypothalamus and/or adenohypophysis in a bird, using intrahypothalamic implants of oestradiol. The results suggest that this system exists (Groups 2 and 4; Tables 1 and 2) and that it involves those regions of the hypothalamus that have been implicated previously in the LHcontrol system (Stetson, 1969b, 1971) in this species. The effect of the implant in preventing ovulation, while a normal-sized ovary and oviduct were maintained (see Heald et al., 1968), suggests impairment of normal function of the LH-release system. Although it is not possible to state with certainty that ovarian (follicular) and oviducal size in Groups 2 and 4 were maintained at normal preovulatory levels throughout the postoperative delay to the onset of oviposition, two facts suggest that this was so: (a) the birds in Group 2 from the short-term experiment had not ovulated (examination of the ovaries revealed no recent postovulatory follicles, and no signs of ova or yolk were observed in the oviduct and abdominal cavity) at the time of autopsy (13 to 14 days after operation), yet the weights of the ovaries and oviducts and follicular diameters were indistinguishable from those of controls, and (b) bilateral electrolytic lesions in the regions of the hypothalamus in which implants resided in Groups 2 and 4 produced identical ovarian dysfunctions. In several birds, the ovary and oviduct were maintained in a preovulatory state from Day 21 (laparotomy) to Day 60 and, in three others, large ovaries and oviducts persisted from Day 21 to Day 133 when the experiment was terminated without a single egg being laid. The results presented here are similar to those reported in the lizard, Sceloporus cyanogenys (Callard \& McConnel, 1969). In mammals, however, 
regression of the ovaries and uterus occurs in rats with implants of oestradiol benzoate in the basal medial hypothalamus, indicating an alteration of the tonic release of FSH or FSH and LH. Implants in the preoptic-anterior hypothalamic region, the 'LH-cyclicity center,' are without effect (Lisk, 1960, 1965; Davidson, 1969).

Since, in the short-term experiment, the ovary and oviduct of birds with effective implants were in a state resembling that of persistent oestrus in mammals, it is unlikely that the implants affected the release of FSH from the adenohypophysis. The release of $\mathrm{LH}$, however, may have been either enhanced or diminished while the release of FSH was either enhanced or remained the same. The bioassay used in this investigation is not specific for a particular pituitary gonadotrophin (Furr \& Cunningham, 1970), but, contrary to the situation in male quail (Stetson, 1972), pituitary gonadotrophic potency was not altered by the implants. This suggests that oestradiol feedback is not inhibitory. The possibility exists (Gay, Midgley \& Niswender, 1970) that high or increasing concentrations of circulating oestrogens may trigger the preovulatory release of $\mathrm{LH}$, or $\mathrm{LH}$ and $\mathrm{FSH}$, resulting in ovulation of the largest follicle and perhaps a concomitant, though relatively brief, decrease in plasma oestrogen levels. In this instance, a true inhibitory feedback (Stetson, 1972) would exist whereby oestradiol (testosterone in males) would exert some control over its own rate of release (see Schwartz, 1969; Schwartz \& Waltz, 1970). This model is consistent with the observations of Nalbandov (1953), Breneman (1955) and Heald et al. (1968) who describe high levels of circulating oestrogens preceding ovulation in the domestic fowl. It could also explain the results of Fraps (1954, 1955 ) in the same species, who found that a single intravenous injection of oestradiol ( 1.0 or $2.5 \mathrm{mg} / \mathrm{bird}$ ) prevented the second, but not the first ovulation in a clutch of eggs, whereas injections of smaller amounts of the hormone $(0.2$ to $0.5 \mathrm{mg} / \mathrm{bird}) \mathrm{had}$ no effect.

In females as in males (Stetson, 1972), the steroid-sensitive areas in the hypothalamus appear to be situated centrally, or just lateral to the mid-line (Pl. 1, Figs 2, 3 and 5). The adenohypophysis cannot be excluded as a possible site of action of oestradiol. The implant in one bird of Group 2 was located primarily within the cephalic lobe of the adenohypophysis, and resulted in an 18-day delay in oviposition. Since there was some overlap in the location of effective and ineffective implants in both the ventral infundibular and preoptic regions of the hypothalamus, and since all but two of the ineffective implants were glass capillaries of narrow diameter (see Text-fig. 1), the criterion determining efficacy of an implant may be the volume of tissue contacting the steroid.

The effects observed in Groups 2 and 4 (Text-fig. 1, Table 1) probably represent a direct and localized action of the steroid; it is unlikely that interruption of ovulation resulted from peripheral diffusion of the steroid, unless perhaps such diffusion was ventral, toward the adenohypophysis (see Palka, Ramirez \& Sawyer, 1966). It is equally unlikely that the effects observed in Groups 2 and 4 resulted from the creation of a physical lesion since (a) unilateral electrolytic lesions approximating to the size of the implants $(0.4 \times$ $0.5 \mathrm{~mm}$ ) were ineffective when located in similar regions of the hypothalamus 
of female quail (Stetson, 1971), (b) the effect was temporary, despite the persistence of the implant (P1. 1, Figs 1 to 6) and (c) implants of cholesterol, of similar size and location, were without effect.

\section{ACKNOWLEDGMENTS}

This investigation was supported by NIH Predoctoral Fellowship GM-33,458 to the author and by NIH (NB-06187) and NSF (GB-5969) Research Grants to Professor Donald S. Farner. I wish to thank Professor Farner and Professor Bronson for their critical evaluation of this manuscript and suggestions for its improvement. This paper is based on a dissertation submitted in partial fulfilment of the requirements for the degree of Doctor of Philosophy in Zoology from the University of Washington. The protein hormones used in this investigation were generously supplied by the Endocrine Study Section of the National Institute of Health.

\section{REFERENGES}

Arimura, A. \& Schally, A. V. (1971) Augmentation of pituitary responsiveness to LH-releasing hormone (LH-RH) by estrogen. Proc. Soc. exp. Biol. Med. 136, 290.

Barraclough, G. A. \& Halier, E. W. (1970) Positive and negative feedback effects of estrogen on pituitary LH synthesis and release in normal and androgen-sterilized female rats. Endocrinology, 86, 542 .

BLIss, C. I. (1952) The statistics of bioassay with special reference to the vitamins. Academic Press, New York.

Breneman, W. R. (1955) Reproduction in birds: the female. Mem. Soc. Endocr. 4, 94.

Breneman, W. R., Zeller, F. J. \& Creek, R. O. (1962) Radioactive phosphorus uptake by chick testes as an end-point for gonadotrophin assay. Endocrinology, 71, 790.

GALlaRd, I. P. \& McConnel, W. F. (1969) Effects of intrahypothalamic estrogen implants on ovulation in Sceloporus cyanogenys. Gen. comp. Endocr. 13, 496.

Davidson, J. M. (1969) Feedback control of gonadotropin secretion. In: Frontiers of Neuroendocrinology, p. 343, Eds W. F. Ganong and L. Martini. Oxford University Press, London.

Davidson, J. W., Weick, R. F., Smrth, E. R. \& Dominguez, R. (1970) Feedback mechanisms in relation to ovulation. Fedn Proc. Fedn Am. Socs exp. Biol. 21, 1900.

FLERKó, B. (1966) Control of gonadotropin secretion in the female. In. Neuroendocrinology, Vol. 1, p. 613, Eds. L. Martini \& W. F. Ganong. Academic Press, New York.

FleRKó, B. (1967) Action of hormones on the neural mechanisms controlling gonadotropin secretion. Archs Anat. microsc. Morph. exp. 56, 446.

Folletr, B. K. \& FARNer, D. S. (1966) Pituitary gonadotropins in the Japanese quail (Coturnix coturnix japonica) during photoperiodically induced gonadal growth. Gen. comp. Endocr. 7, 125.

FRAPS, R. M. (1954) Neural basis of diurnal periodicity in release of ovulation-inducing hormone in fowl. Proc. natn. Acad. Sci. U.S.A. 40, 348.

Fraps, R. M. (1955) The varying effects of sex hormones in birds. Mem. Soc. Endocr. 4, 205.

FurR, B. J. A. \& Cunningham, F. J. (1970) The biological assay of chicken pituitary gonadotropins. Br. Poultry Sci. 11, 7.

Gay, V. L., Midgley, A. R., JR \& Niswender, G. D. (1970) Patterns of gonadotropin secretion associated with ovulation. Fedn Proc. Fedn Am. Socs exp. Biol. 29, 1880.

Gogan, F. (1967) Action de la testostérone sur la gonadostimulation par la lumière chez le canard Pékin. Biologie méd. 56, 369.

Gogan, F. (1968) Sensibilité hypothalamique à la testostérone chez le canard. Gen. comp. Endocr. 11, 316.

Gogan, F. \& Kordon, G. (1964) Influence du feed-back par la testostérone sur la gonadostimulation induite par la lumière chez le canard. F. Physiol., Paris, 56, 364.

HARRIs, G. W. \& GAMpBelz, H. J. (1966) The regulation of the secretion of luteinizing hormone and ovulation. In: The Pituitary Gland. Vol. 2, p. 99. Eds. G. W. Harris and B. T. Donovan. University of California Press, Berkeley.

Heald, P. J., Rookledge, K. A., Furnival, B. E. \& Watts, G. D. (1968) The effects of gonadal hormones on the levels of pituitary luteinizing hormone in the domestic fowl. F. Endocr. 41, 313. 
Kовауазні, H. (1954) Inhibition by sex steroids and thyroid substance of light-induced gonadal development in the passerine bird Zosterops palpebrosa japonica. Endocr. jap. 1, 51.

Kordon, G. \& GoGAN, F. (1964) Localisation par une technique de micro-implantation de structures hypothalamiques responsables du feed-back par la testostérone chez le canard. C. r. Séanc. Biol. $158,1795$.

KoRDon, C. \& Gogan, F. (1970) Interaction du feed-back de la photostimulation dans les régulations gonadotropes chez le mammiféres et les oiseaux. In: La Photoregulation de la Reproduction chez les Oiseaux et les Mammiferes, p. 325. Eds. J. Benoit and I. Assenmacher. Coll. Intern. G.N.R.S., No. 172, Paris.

Lisk, R. D. (1960) Estrogen-sensitive centers in the hypothalamus of the rat. F. exp. Zool. 145, 197.

LIsk, R. D. (1965) Reproductive capacity and behavioural oestrus in the rat bearing hypothalamic implants of sex steroids. Acta endocr., Copenh. 48, 209.

LORENZ, F. W. (1954) Effects of estrogens on domestic fowl and applications in the poultry industry. Vitams Horm. 21, 235.

Nalbandov, A. V. (1953) Endocrine control of physiological functions. Poult. Sci. 32, 88.

PALKA, Y. S., RAMIREz, V. D. \& SAWYER, C. H. (1966) Distribution and biological effects of tritiated oestradiol implanted in the hypothalamo-hypophysial region of female rats. Endocrinology, 78, 487.

Parkes, A. S. \& Emmens, C. W. (1944) Effect of androgens and oestrogens on birds. Vitams Horm. 2, 361.

Schwartz, N. B. (1969) A model for the regulation of ovulation in the rat. Recent Prog. Horm. Res. 25,1 .

Schwartz, N. B. \& Waltz, P. (1970) Role of ovulation in the regulation of the oestrous cycle. Fedn Proc. Fedn Am. Socs exp. Biol. 29, 1907.

Stetson, M. H. (1968) Placement of electrodes in specific sites in the brains of small birds. Gen. comp. Endocr. 10, 445.

Strtson, M. H. (1969a) The role of the median eminence in control of photoperiodically induced testicular growth in the White-crowned Sparrow, Zonotrichia leucophrys gambelii. Z. Zellforsch. mikrosk. Anat. 93, 369.

StETsON, M. H. (1969b) Hypothalamic regulation of FSH and LH secretion in male and female Japanese quail. $A m$. Zoologist, 9, 1078.

STETson, M. H. (1971) Control mechanisms in the avian hypothalamo-hypophysio-gonadal axis. Ph.D. dissertation, University of Washington.

Stetson, M. H. (1972) Feedback regulation of testicular function in Japanese quail: testosterone implants in the hypothalamus and adenohypophysis. Gen. comp. Endocr. 19, 37.

Weick, R. F. \& Davidson, J. M. (1970) Localization of the stimulatory feedback effect of estrogen on ovulation in the rat. Endocrinology, 87, 693.

WrLson, F. E. (1970) The tubero-infundibular neuron region of the hypothalamus: A focus of testosterone sensitivity in male Tree Sparrows (Spizella arborea). In: Aspects of Neuroendocrinology, p. 274. Eds. W. Bargmann and B. Scharrer. Springer, Heidelberg. 